Article

\title{
Mobility from Renewable Electricity: Infrastructure Comparison for Battery and Hydrogen Fuel Cell Vehicles
}

\author{
Yorick Ligen *, Heron Vrubel and Hubert H. Girault
}

Ecole Polytechnique Federale de Lausanne (EPFL), Laboratoire d'Electrochimie Physique et Analytique (LEPA), Rue de l'Industrie 17, CH-1951 Sion, Switzerland; heron.vrubel@epfl.ch (H.V.); hubert.girault@epfl.ch (H.H.G.)

* Correspondence: yorick.ligen@epfl.ch

Received: 4 May 2018; Accepted: 21 May 2018; Published: 24 May 2018

check for updates

\begin{abstract}
This work presents a detailed breakdown of the energy conversion chains from intermittent electricity to a vehicle, considering battery electric vehicles (BEVs) and fuel cell electric vehicles (FCEVs). The traditional well-to-wheel analysis is adapted to a grid to mobility approach by introducing the intermediate steps of useful electricity, energy carrier and on-board storage. Specific attention is given to an effective coupling with renewable electricity sources and associated storage needs. Actual market data show that, compared to FCEVs, BEVs and their infrastructure are twice as efficient in the conversion of renewable electricity to a mobility service. A much larger difference between BEVs and FCEVs is usually reported in the literature. Focusing on recharging events, this work additionally shows that the infrastructure efficiencies of both electric vehicle (EV) types are very close, with $57 \%$ from grid to on-board storage for hydrogen refilling stations and $66 \%$ for fast chargers coupled with battery storage. The transfer from the energy carrier at the station to on-board storage in the vehicle accounts for $9 \%$ and $12 \%$ of the total energy losses of these two modes, respectively. Slow charging modes can achieve a charging infrastructure efficiency of $78 \%$ with residential energy storage systems coupled with AC chargers.
\end{abstract}

Keywords: electric vehicle; hydrogen; fuel cell vehicle; charging efficiency; energy consumption; charging infrastructure

\section{Introduction}

The transport sector contributes to two major environmental issues on both the local and global scale. First, urban areas are affected by high levels of noise and air pollution (PM10, $\mathrm{NO}_{x}, \mathrm{SO}_{\mathrm{x}}, \mathrm{CO}$, etc.), and second, fossil fuel combustion in diesel and gasoline engines releases $\mathrm{CO}_{2}$ into the atmosphere, contributing to global warming. Electric vehicles (EVs) address both issues: the first one as a direct consequence of electric drivetrains and the lack of fossil fuel combustion and the second one in parallel with the growing share of renewables in the electricity mix. The principle of sector coupling (SC) was introduced in order to take the full benefits of the stochastic nature of wind and solar energy for industrial, mobility and residential applications [1]. In this work, passenger transportation with battery electric vehicles (BEVs) and hydrogen fuel cell vehicles (FCEVs) is investigated. In the spirit of SC, electrolytic hydrogen production was considered rather than coal gasification, natural gas, biomass or direct solar pathways. This work compares the energy conversion chains and infrastructures required to deliver an effective driving range for EVs. Taking into account the whole energy chain, from renewable electricity to useful energy in the vehicle and eventually the distance covered with one electric charge or a hydrogen refill, it presents an updated and realistic comparison of practical ranges achievable with a given amount of renewable electricity. 


\section{Infrastructure Specifications to Couple EV Charging with Renewables}

EVs require a specific charging infrastructure to either recharge batteries or refill hydrogen tanks, similarly as conventional refueling stations are needed for internal combustion engines vehicles (ICEVs). One of the major barriers to the commercialization success of EVs is the availability of these infrastructures, and simultaneously, without EVs on the road, the incentives to build a network are limited. However, BEVs and FCEVs are not equally impacted by this issue. Indeed, several options are available for BEVs: they could be recharged at home from an AC source using a standard domestic outlet or at public charging stations. It is estimated that $80 \%$ of the recharging events will occur at slow charging rates at home or at the office [2]. However, for the remaining $20 \%$, the fast charging options for BEVs still require significantly longer stops compared to other energy carriers (Table 1). In contrast, the only refilling option for FCEVs is the hydrogen refilling station (HRS), allowing a full refill within $3 \mathrm{~min}$ [3], but currently, it is limited to a few sites. The autonomy flow rate, giving the range regained per minute of charge or refill, is a critical differentiating factor between charging modes for passenger vehicles and affects driver's behavior and consumer's choices. Table 1 gives an overview of the various options available.

Table 1. Autonomy flow rates (adapted from [4]).

\begin{tabular}{lllll}
\hline Vehicle Type & BEV & BEV & FCEV & ICEV \\
\hline Charging mode & Home charging & Fast charging & HRS & $\begin{array}{l}\text { Conventional } \\
\text { refilling station }\end{array}$ \\
ine Energy carrier flow rate & $2-6 \mathrm{~kW}$ & $50 \mathrm{~kW} \mathrm{up} \mathrm{to} 150 \mathrm{~kW}$ & up to $2 \mathrm{~kg} \cdot \mathrm{min}^{-1}$ & $35 \mathrm{~L} \cdot \mathrm{min}^{-1}$ \\
ine Autonomy flow rate & $0.2-0.6 \mathrm{~km} \cdot \mathrm{min}^{-1}$ & $3-5 \mathrm{~km} \cdot \mathrm{min}^{-1}(50 \mathrm{~kW})$ & $160-220 \mathrm{~km} \cdot \mathrm{min}^{-1}$ & $370-430 \mathrm{~km} \cdot \mathrm{min}^{-1}$ \\
\hline
\end{tabular}

For comparison purposes, the Hyundai ix35, available either with a fuel cell or with an internal combustion engine, was taken as a reference for the gasoline case $(9.4 \mathrm{~L} / 100 \mathrm{~km})$. The upper bound of the autonomy flow rate is based on a gasoline VW Golf consuming $8.0 \mathrm{~L} / 100 \mathrm{~km}$. For BEVs, the upper bound is based on the Hyundai Ioniq electric $(15.5 \mathrm{kWh} / 100 \mathrm{~km})$, and the lower bound is based on the BYD e6 (29 kWh/100 km). All vehicle consumptions are based on [5].

Additionally, the autonomy flow rate represents a significant constraint for infrastructure operators willing to serve a maximum number of customers per day. According to the Swiss oil industry [6] and the Swiss Federal Office for roads [7], the average refueling station in Switzerland delivers around $46,000 \mathrm{~km}$ of autonomy to its customers every day. This autonomy delivered to a set of vehicles is defined as a mobility service. To deliver the same mobility service within the opening hours, at least 11 chargers at $50 \mathrm{~kW}$ must be operated simultaneously with no interruption, and an HRS should deliver $460 \mathrm{~kg}$ of hydrogen. The required infrastructure to deliver this mobility service using intermittent renewable electricity sources is described in the following paragraphs.

\subsection{Battery Electric Vehicle Infrastructure}

$\mathrm{BEV}$ can be either recharged with AC sources, using the converter placed on-board the vehicle, or with DC chargers. AC mode is typically limited to 3-6 kW (AC Types 1 and 2) and is usually associated with domestic chargers and overnight charging. DC sources, or fast chargers, can deliver up to $150 \mathrm{~kW}$ using actual connectors (CCS, CHAdeMo, Tesla).

For the coupling with renewable electricity, two similar strategies (but at different scales) can be adopted for individuals (AC chargers) and fast charging stations operators (DC chargers). The idea is to introduce a buffer energy storage system (ESS) to take into account the intermittency of the renewable electricity production and to be able to fulfill charging demand at any time.

For individuals, several manufacturers offer small power packs or residential ESS in the range of 5-30 kWh. These systems can be used to store the energy produced with solar panels on the roof, to ensure energy autonomy of the household during power cuts or to accommodate time-of-use or demand charge rate schemes. 
For station operators, buffer batteries offer additional benefits such as lowering the power connection requirements and relaxing the constraints on the grid. Tsirinomeny [8] estimated a typical battery for a station serving $200 \mathrm{BEVs} /$ day to have a capacity of $2.2 \mathrm{MWh}$ and a maximum power output of 1.6 MW (32 chargers at $50 \mathrm{~kW}$ with a peak grid demand of $400 \mathrm{~kW}$ ).

Even if most of the energy losses will be associated with this intermediate storage, the vehicle side is often overlooked. Both charging modes are significantly affected by vehicle side components, such as the on-board converter for AC charging and the cooling via the battery management system (BMS) during fast charge. Additionally, we can mention some losses occurring within the charger to cool down the cord, which is expected to be required above $150 \mathrm{~kW}$.

\subsection{Hydrogen Fuel Cell Electric Vehicle Infrastructure}

The infrastructure required to refill FCEVs comprises:

- A hydrogen production unit: A variety of techniques is used to produce hydrogen, but the only one currently available and directly related to renewable electricity at a large scale is water electrolysis, with two mature technologies at low temperatures: alkaline or proton exchange membrane (PEM) electrolyzers. Additionally, if the hydrogen is not produced on-site, it has to be transported in gaseous form, typically in tube trailers at $20 \mathrm{MPa}$.

- A hydrogen storage system (supply storage): usually gaseous hydrogen at 4-20 MPa in steel cylinders.

- A hydrogen compression system: Several compressor technologies are available such as diaphragm or reciprocating compressors, comprising, for example, gas booster or ionic compressors, similar to the one developed by Linde [9].

- A hydrogen buffer or fueling storage: usually organized in a cascade system up to $90 \mathrm{MPa}$ according to the National Renewable Energy Laboratory (NREL) recommendations [10].

- A dispenser: includes a fueling nozzle to connect to the car and a cooling block to precool the hydrogen. Indeed, the hydrogen in the vehicle tank is subjected to a rapid recompression throughout the fill, which generates heat, in addition to the Joule-Thomson effect at the fueling nozzle [11]. High temperatures can lead to an under filling of the tank, but also can damage the composite layer of the hydrogen tank. According to the fueling protocol SAE J2601 [3], a precooling temperature of $-40{ }^{\circ} \mathrm{C}$ is recommended. Finally, in order to release the pressure in the fueling nozzle at the end of the refilling, the hydrogen contained in the hose between the last valve of the HRS and the entry point of the vehicle is vented into the air.

\subsection{Summary of Required Layouts}

Extremely diverse layouts can be proposed for EV refilling infrastructure coupled with renewables. For illustrative purposes, the minimal layout is represented in the graph below, assuming an HRS with on-site electrolysis. The scope and boundaries of the study are summarized in Figure 1 below. 


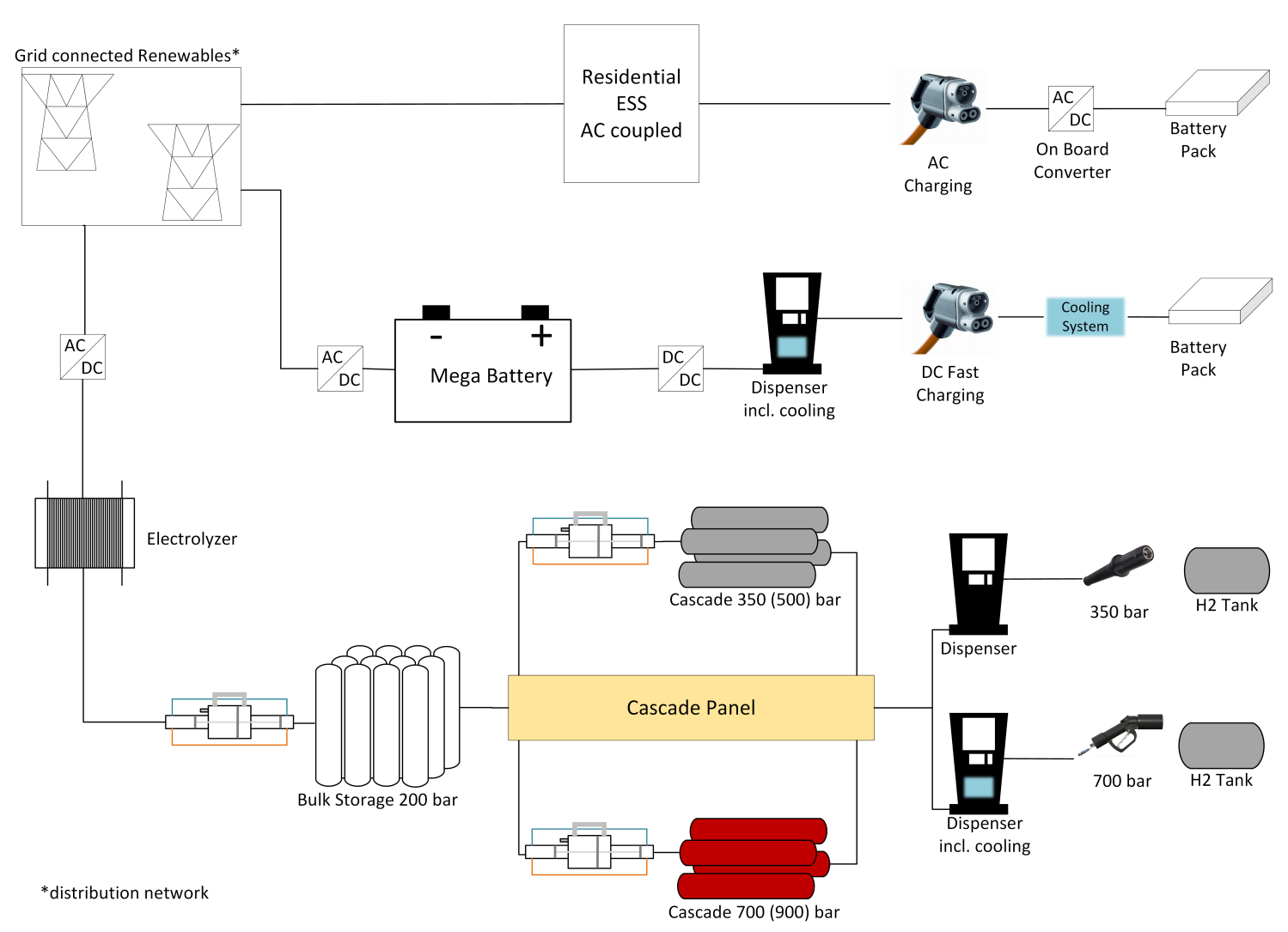

Figure 1. EVs' refilling pathways.

\section{Novel Method for Grid to Mobility Assessments}

Life cycle assessment (LCA) applied to the transport sector is usually broken down into the well-to-wheel (WtW) analysis approach for the usage phase [12]. Conceived originally for ICEVs as the reference case, refilling events are not explicitly highlighted, and the methodology does not fit the specificities of EVs. Indeed, well-to-tank (WtT) usually covers the energy carrier production and transport, and tank-to-wheel (TtW) covers the energy consumption of the vehicle, but the distribution of the energy carrier to the vehicle is hidden in the $\mathrm{WtT}$ part and is therefore often neglected.

\subsection{Literature Review}

An extensive literature is available on BEVs' and FCEVs' energy intensity, with several efficiency comparisons. However, the results are extremely diverse, ranging from BEVs being 1.25-3.9-times more energy efficient than FCEVs [13-18]. The main difference originates from the system definition, especially regarding the site of hydrogen production (transport required or not), the primary energy source and the useful unit considered (energy out of the motor or converted into effective distance driven). In addition, a detailed description of recharging events and the coupling with renewables are rarely addressed. Too often, BEVs' losses are solely based on charging and discharging of the on-board battery, while FCEVs' losses include electrolyzer, compressor and fuel cell operation. The influence of charging events is mostly considered via the charging time or the electricity mix used, and the mode of charging (fast or slow) was anticipated to have an impact on the aging of batteries, but not explicitly on the efficiency [19].

Most of these studies were published prior to 2010, before the momentum towards fast DC charging (the SAE J1772 incorporated DC charging only in its 2012 revision [20]) and the definition of a standardized hydrogen refilling protocol (the first version of the SAE J2601 was published in 2010 [3]). As a consequence, BEV charging efficiencies are quite accurate when referring to slow charging modes, but inadequate for assessments with fast charging modes. Concerning FCEVs, only a 
limited energy system analysis of the refilling process has been provided yet with primary data coming from demonstrators [21,22]. In order to address these gaps, we introduced a new segmentation and adapted the WtW approach to EV specificities.

\subsection{Grid to Mobility Approach}

Based on the pathways defined in Figure 1, we can identify a pattern in the conversion of intermittent grid electricity to a mobility service for EV drivers.

i Grid to useful electricity:

Useful electricity is considered as electricity compatible with the main equipment of the refilling infrastructure. Electrochemical devices, either batteries or electrolyzers, operate on DC currents; therefore, preliminary AC/DC conversion is usually required, except in the case when a direct DC coupling with solar panels is feasible or if the ESS includes the converter.

ii Useful electricity to energy carrier:

Two different energy carriers are commercially investigated for EVs: electricity stored in batteries or hydrogen. We define the energy carrier as the energy stored in large quantities at the station for grid independent refueling at any point in time. It covers the use of megabatteries (MW/MWh), and the operation of electrolyzers and first compression steps for the bulk storage of hydrogen.

iii Energy carrier to on-board storage:

Refilling and recharging events were often neglected for ICEVs due to the very simple equipment required and the insignificant energy consumption in that case. However, for EVs, this step can be particularly challenging. For example, both BEVs and FCEVs require thermal management systems.

iv On-board storage to mobility:

After all the conversions occurring prior to and during charging events, the energy transferred is ultimately converted into a mobility service for the driver. The energy stored on-board is converted into $\mathrm{km}$ driven, which is assessed on standardized driving cycles such as those conducted by the U.S. Environmental Protection Agency (EPA).

\section{Case Study and Data Collection}

The subdivisions presented in Section 3.2 are applied to the typical set of refilling modes for BEVs and FCEVs. The corresponding equipment and processes investigated are summarized in Table 2. Efficiency estimates are based on the literature and published data for commercially available products.

Table 2. Grid to mobility segmentation.

\begin{tabular}{llll}
\hline Step & BEV Slow & BEV Fast & FCEV 35 MPa and 70 MPa \\
\hline Grid to useful electricity & No conversion required & AC/DC conversion & AC/DC conversion \\
\hline $\begin{array}{l}\text { Useful electricity to energy } \\
\text { carrier }\end{array}$ & $\begin{array}{l}\text { Storage in stationary battery } \\
\text { AC coupled }\end{array}$ & $\begin{array}{l}\text { Storage in stationary battery } \\
\text { DC coupled }\end{array}$ & $\begin{array}{l}\text { Variable load electrolysis } \\
\text { Purification } \\
20 \text { MPa compression }\end{array}$ \\
\hline $\begin{array}{l}\text { Energy carrier to on-board } \\
\text { storage }\end{array}$ & On-board AC/DC conversion & $\begin{array}{l}\text { DC/DC conversion } \\
\text { Battery thermal management }\end{array}$ & $\begin{array}{l}50-\mathrm{MPa} \text { cascade compression } \\
90-\mathrm{MPa} \text { cascade compression } \\
-40{ }^{\circ} \mathrm{C} \text { precooling } \\
\text { Dispenser vent }\end{array}$ \\
\hline On-board storage to mobility & EPA combined cycle & EPA combined cycle & EPA combined cycle \\
\hline
\end{tabular}




\section{1. $B E V$}

We consider AC and DC charging modes, in order to evaluate the conversion of $\mathrm{kWh}$ of intermittent electricity to $\mathrm{km}$ driven with a BEV. Without constraints and incentives to adapt charging schedules, production and consumption cannot match and require therefore the introduction of storage systems.

\subsubsection{Stationary Storage}

For domestic installations, renewable electricity can be locally produced with solar panels. Even if the current produced is already in a DC form, residential ESS are usually AC coupled, requiring the use of inverters. Round trip AC efficiencies reported by various manufacturers of lithium-ion residential ESS are between $89 \%$ and $92 \%$ [23,24]. For commercial installations, batteries in the MWh range are required. Several technologies are available, and we can mention, for example, flow batteries (e.g., all vanadium or zinc bromine), lithium-ion, lithium polymer and lithium titanate. Introducing mega batteries in stations with multiple fast chargers has several benefits such as peak shaving, load leveling and buffering, as well as relaxing the constraints for grid connection $[4,8,25]$. A real implementation of a DC fast charging station coupled with a battery storage system was performed by Sbordone et al. [26] with a peak shaving strategy. The system efficiency is highly dependent on the chemistry of the battery with reported efficiencies ranging from $65-90 \%$.

\subsubsection{Dispenser and Charging Events}

Losses are also reported during charging events due to power electronics and thermal management. AC charging mode involves the use of the charger on-board the vehicle, which is basically an AC/DC converter. The Idaho National Laboratory (INL) performed test bench measurements with various BEVs and reported charging efficiencies in the range of 85-92\% [27]. The INL also investigated fast DC charges and especially the consumption of the battery management system. The energy used during fast charge events for the cooling was found to be in the range of 3-5\% (and up to $10 \%$ in hot weather conditions) of the total energy transferred to the battery [27]. These energy expenses are expected to increase with fast charging capabilities, especially above $150 \mathrm{~kW}$, when cooling of the charging cord will also be required. Finally, the efficiencies reported by fast charger manufacturers usually account for the AC/DC conversion, so a typical value of $98 \%$ for a DC/DC is used.

\subsubsection{Vehicle Efficiency}

According to EPA measurements, consumption of BEVs varies in the range of $15-29 \mathrm{kWh} / 100 \mathrm{~km}$ (Hyundai Ioniq to BYD e6 [5]).

\subsection{FCEV}

Unlike BEV infrastructures, FCEV infrastructures integrate by definition storage capacity and some flexibility in the energy carrier production. No simultaneity is required between hydrogen production and hydrogen delivery.

\subsubsection{Electrolysis}

Commercially available proton exchange membrane (PEM) or alkaline electrolyzers can achieve a system consumption in the range of $4.0-5.0 \mathrm{kWh} / \mathrm{Nm}^{3}[12,28]$. Slightly higher values are reported by NOW [29]: in the range of $4.5-7.0 \mathrm{kWh} / \mathrm{Nm}^{3}$, expected to go down to $4.3-5.7 \mathrm{kWh} / \mathrm{Nm}^{3}$ or 4.1-4.8 kWh $/ \mathrm{Nm}^{3}$ within 10-20 years for alkaline and PEM electrolyzers, respectively. If electrolysis cannot be performed on site, an additional penalty for transportation in the tube trailer would be around $0.6 \mathrm{kWh} / \mathrm{kg} \mathrm{H}_{2}$ transported [30]. 


\subsubsection{Compression}

Practical measured compression energy varies from $2.7-4.2 \mathrm{kWh} / \mathrm{kg} \mathrm{H}_{2}$ [31] for $90 \mathrm{MPa}$. At the station at the University of California-Irvine (UCI) [22], a consumption of $2.68 \mathrm{kWh} / \mathrm{kg} \mathrm{H}_{2}$ was achieved, and 70-MPa refills exhibited only $11 \%$ more compression energy consumption than the 35-MPa refills. In order to make the distinction between the compression required for the supply storage (energy carrier stage) and the one required for the refilling (energy carrier to on-board storage), the following conversion efficiency values were adopted:

- $\quad 95 \%$ for $20 \mathrm{MPa}$ (nominal pressure of supply storage systems) starting from the outlet pressure of the electrolyzer, corresponding to $1.8 \mathrm{kWh} / \mathrm{kg} \mathrm{H}_{2}$.

- $\quad 98 \%$ and $97 \%$ for respectively 35-MPa and 70-MPa refills, corresponding in total to $2.5 \mathrm{kWh} / \mathrm{kg}$ $\mathrm{H}_{2}(93 \%)$ and $2.8 \mathrm{kWh} / \mathrm{kg} \mathrm{H}_{2}(92 \%)$, in line with the $11 \%$ difference reported by UCI [22] and with the numbers published by Stolten [30].

Efficiency improvements for the compression work are limited by the cascade design and thermodynamics: a perfect isothermal compression at $70 \mathrm{MPa}$ would require $2.1 \mathrm{kWh} / \mathrm{kg} \mathrm{H}_{2}$.

\subsubsection{Precooling and Refilling Event}

Precooling is one of the critical processes to allow a fast refilling of FCEVs at $70 \mathrm{MPa}$. High pressure hydrogen needs to go through a heat exchanger before being transferred to the car via the filling nozzle. The cooling block is usually maintained at $-40{ }^{\circ} \mathrm{C}$ in order to keep the station ready at any point of time. As a consequence, the energy requirement for cooling reported per kilogram of hydrogen delivered ranges from above $20 \mathrm{kWh} / \mathrm{kg} \mathrm{H}_{2}$ (HRS with low frequentation in Germany [32]) to only $1.4 \mathrm{kWh} / \mathrm{kg} \mathrm{H}_{2}$ (HRS with attached fleet [22]). Elgowainy and Reddi [33] estimated that, for high HRS capacity utilization, the electricity consumption for $\mathrm{H}_{2}$ precooling can be even lower than $1 \mathrm{kWh} / \mathrm{kg}$ $\mathrm{H}_{2}$. Additionally, another process causes losses during the refilling: the remaining hydrogen in the hose has to be vented in order to release the coupling. Considering a hose of six meters under $70 \mathrm{MPa}$ [34], approximately $7 \mathrm{~g}$ of hydrogen is vented after each refill. This quantity is negligible.

\subsubsection{Vehicle Efficiency}

Similarly, as for BEV, the U.S. EPA also measured efficiencies of the conversion from on-board storage to mobility for FCEVs. The measured figures vary from $0.92-1.26 \mathrm{~kg} \mathrm{H}_{2} / 100 \mathrm{~km} \mathrm{[5];} \mathrm{however,}$ the set of commercially available vehicles is still limited.

\subsection{Results and Discussion}

The mobility service achievable with $100 \mathrm{kWh}$ of intermittent electricity and the corresponding losses along the grid to mobility pathway are presented in Figure 2. In order to observe the final conversion into mobility service at the same scale, an arbitrary scaling factor is fixed in order to highlight a typical $46 \%$ efficiency of the fuel cell drive train [17].

\subsubsection{Discussion}

For all modes, most of the infrastructure losses occur during the conversion from useful electricity to energy carrier. Refilling events (energy carrier to on-board storage) have a limited contribution in the overall efficiency except for home charging. Finally, considering the grid to on-board storage conversion, the fast charging infrastructure for BEVs is only $15 \%$ more effective than HRS, and only two thirds of the initial energy effectively reach the vehicle. The vehicle side conversion is the discriminating criterion. That is why hybrid FCEV concepts with optimized battery size and fuel cell power can offer significant advantages [35]. 


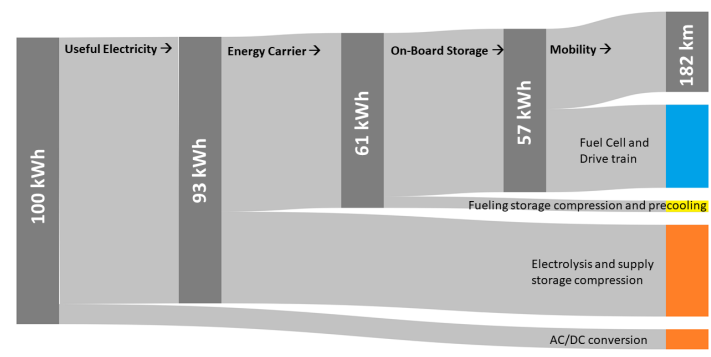

(a)

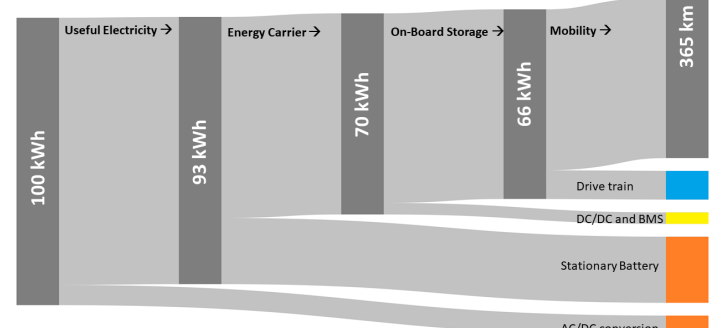

(c)

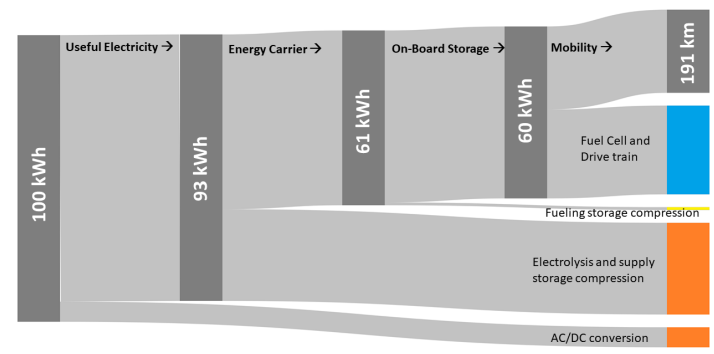

(b)

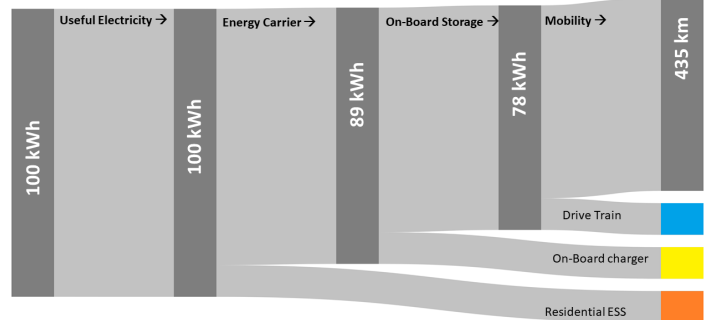

(d)

Vehicle losses in operation

Losses associated with the charging event

Intermittent electricity to energy carrier losses

Figure 2. Sankey diagram of the grid to mobility conversion efficiencies for (a) $70 \mathrm{MPa} \mathrm{H}_{2}$, (b) $35 \mathrm{MPa}$ $\mathrm{H}_{2}$, (c) 50-kW fast charger coupled to a stationary battery and (d) a home charger coupled with a residential ESS. (a) $70 \mathrm{MPa}$; (b) $35 \mathrm{MPa}$; (c) fast charging; (d) home charging.

Interestingly, increasing the delivery pressure from $35 \mathrm{MPa}$ to $70 \mathrm{MPa}$ only costs $5 \%$ more energy. The large difference observed between the two BEV modes is mainly due to the fact that a less efficient technology was selected for the megabattery (75\%) compared to the residential ESS (89\%), to depict the likely investment decision of station operators and the numbers reported in Section 4.1.1. The impact of these values is investigated in the sensitivity analysis.

For comparison, we can note that introducing $57 \mathrm{kWh}$ of energy (the FCEV 70-MPa case) in the form of gasoline in an ICEV will offer only $100 \mathrm{~km}$ of driving range (not to mention that all upstream conversions are also energy intensive).

\subsubsection{Sensitivity Analysis}

As highlighted in Sections 4.1 and 4.2, some of the major components of EV charging infrastructures exhibit very diverse efficiencies. To illustrate how some single components of the grid to mobility conversion chain affect the final results, a sensitivity analysis was performed. The results are presented in Figure 3. Lab- and pilot-scale installations may report numbers outside of the mentioned ranges, but the general trend is shown in this tornado chart.

The graph presented in Figure 3 is also a way to estimate how future technologies' developments will affect the BEV versus FCEV competition. Indeed, the FCEV market and technology are in an earlier stage of development than BEV, and larger efficiency gains, especially on the vehicle side, are expected. On the other hand, the BEV market is going toward longer range and larger vehicles. Thus, we can expect some increase in their energy consumption per kilometer. With BEVs and FCEVs covering more segments of the passenger vehicle market in the future, a more specific comparison could be made. Regarding infrastructure, the efficiency of the electrochemical device used to produce or store the energy carrier is clearly the discriminating parameter. In a SC perspective, the flexibility of this device should also be considered. Finally, limited gains can be made on hydrogen compression, 
as optimized pressure cascades have a greater impact on economics than on energy efficiency [36]. The energy consumption associated with hydrogen precooling is mostly related to the utilization ratio of the station and not related to technological developments [37]. The expected development of 350-kW ultra-fast DC chargers after 2020 will be accompanied with larger losses from the BMS, and the cooling of the charging cord should be added in the overall DC/DC efficiency. Even if the performance specifications of ultra-fast chargers are not yet publicly available, the overall picture will remain similar, according to the relative importance of BMS and DC/DC.

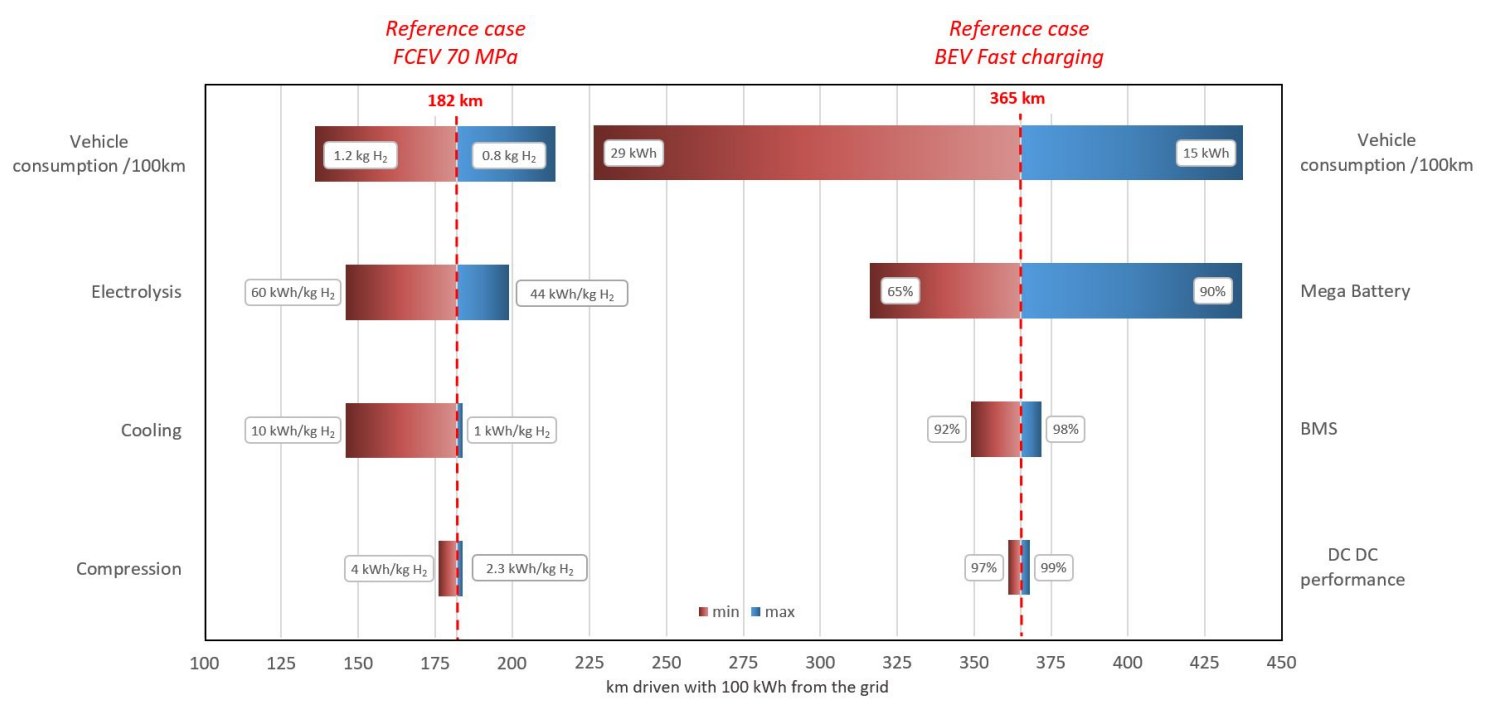

Figure 3. Sensitivity analysis.

Additional considerations such as waste heat utilization and winter effects can heavily affect the energy consumption of BEVs [38] and cannot be observed with traditional TtW approaches. Simulation results performed by Li et al. [17] show that with the heating system activated, the on-board storage to mobility efficiency of BEVs goes down from $73 \%$ to $45 \%$, as compared with the $46 \%$ down to $39 \%$ for FCEVs.

\section{Conclusions}

The development of electric mobility is often understood as the development of green mobility. However, the link between renewable electricity and mobility, although well defined in theory, is not always converted into effective measures to guarantee this connection. Based on this situation, the scaling of renewable electricity production needs is underestimated, and the benefits of hydrogen mobility are blurred. In order to benchmark and compare EV infrastructures coupled with renewables, a grid to mobility approach was introduced. A comprehensive data collection for all components and processes occurring prior and during charging events was performed to ascertain as realistic efficiencies as possible. First of all, it should be noted that the charging infrastructure is a major contributor to the overall energy efficiency of electric mobility. The exemplary cases presented in this study show that only $57-78 \%$ of the energy from the grid is effectively transferred to the vehicle. Additionally, under the assumptions used in this work, it could be shown that up to $15 \%$ less energy is transferred to BEVs using fast DC chargers compared to domestic AC chargers. For FCEVs, the penalty linked to the production of the energy carrier is partially compensated by the fact that no stationary battery storage system is required. However, the final conversion occurs on-board the vehicle, within the fuel cell, which caps the overall efficiency of FCEV mobility to about half of the $\mathrm{BEV}$ one. Further studies should incorporate cost considerations regarding the infrastructure for electric mobility [39] and appropriate scaling needs [40]. A realistic business case and pricing strategies including the benefits of SC should be developed [18]. Grid-scale equipment such as megabatteries can 
heavily impact the costs of recharging stations and electricity network operators. Upscaling electric mobility needs to be accompanied with effective coupling with intermittent renewable electricity sources. Efficiency considerations might then be balanced with cost and flexibility constraints for grid integration. Furthermore, the scope of the vehicles can be extended to small lorries and buses, which are more and more available with electrified drivetrains in combination with batteries and hydrogen fuel cell range extenders.

Author Contributions: Conceptualization, methodology, investigation and writing, Y.L. Validation and writing review, H.V. Supervision and writing review, H.H.G.

Funding: This research was funded by the Swiss Federal Office for Energy (Grant Number SI/501286-01)

Acknowledgments: This work was performed with the support of the Canton du Valais, SINERGY and the City of Martigny, within a demonstration project aiming at field measurements of efficiency of future refilling stations for EVs in combination with renewable electricity sources.

Conflicts of Interest: The authors declare no conflict of interest. The founding sponsors had no role in the design of the study; in the collection, analyses or interpretation of data; in the writing of the manuscript; nor in the decision to publish the results.

\section{Abbreviations}

The following abbreviations are used in this manuscript:

$\begin{array}{ll}\text { AC } & \text { Alternating current } \\ \text { BEV } & \text { Battery electric vehicle } \\ \text { BMS } & \text { Battery management system } \\ \text { DC } & \text { Direct current } \\ \text { EPA } & \text { Environmental Protection Agency } \\ \text { ESS } & \text { Energy storage system } \\ \text { EV } & \text { Electric vehicle } \\ \text { FCEV } & \text { Fuel cell electric vehicle } \\ \text { HRS } & \text { Hydrogen refilling station } \\ \text { ICEV } & \text { Internal combustion engine vehicle } \\ \text { LCA } & \text { Life cycle assessment } \\ \text { PEM } & \text { Proton exchange membrane } \\ \text { PM } & \text { Particulate matter } \\ \text { SAE } & \text { Society of Automotive Engineers } \\ \text { SC } & \text { Sector coupling } \\ \text { TtW } & \text { Tank-to-wheel } \\ \text { WtT } & \text { Well-to-tank } \\ \text { WtW } & \text { Well-to-wheel }\end{array}$

\section{References}

1. Robinius, M.; Otto, A.; Heuser, P.; Welder, L.; Syranidis, K.; Ryberg, D.; Grube, T.; Markewitz, P.; Peters, R.; Stolten, D. Linking the Power and Transport Sectors-Part 1: The Principle of Sector Coupling. Energies 2017, 10, 956, doi:10.3390/en10070956. [CrossRef]

2. Smart, J.; Schey, S. Battery Electric Vehicle Driving and Charging Behavior Observed Early in The EV Project. SAE Int. J. Alt. Power. 2012, 1, 27-33, doi:10.4271/2012-01-0199. [CrossRef]

3. SAE International. Fueling Protocols for Light Duty Gaseous Hydrogen Surface Vehicles; SAE J2601; SAE International: Warrendale, PA, USA, 2014.

4. Hõimoja, H.; Rufer, A.; Dziechciaruk, G.; Vezzini, A. An ultrafast EV charging station demonstrator. In Proceedings of the 2012 International Symposium on Power Electronics, Electrical Drives, Automation and Motion (SPEEDAM), Sorrento, Italy, 20-22 June 2012; pp. 1390-1395.

5. U.S. Environmental Protection Agency. Fuel Economy of Vehicles. Available online: http:/ /www.fueleconomy. gov/feg/ (accessed on 23 May 2018).

6. Union Pétrolière Suisse. Rapport Annuel 2015. Available online: https://www.erdoel.ch/images/com_ evdocs/ev_jb_2015_fr.pdf (accessed on 23 May 2018). 
7. Office Fédéral des Routes OFROU. Trafic et Disponibilité des Routes Nationales. Technical Report, Département FéDéRal de L'environnement, des Transports, de L'éNergie et de la Communication DETEC, 2015. Available online: https://www.astra.admin.ch/dam/astra/fr/dokumente/abteilung strassennetzeallgemein/verkehrsflussbericht-nationalstrassen-2015.pdf.download.pdf/Trafic\%20et\% 20disponibilit\%C3\%A9\%20des\%20routes\%20nationales\%20-\%20Rapport\%202015.pdf (accessed on 23 May 2018).

8. Tsirinomeny, M.; Hõimoja, H.; Rufer, A.; Dziechciaruk, G.; Vezzini, A. Optimizing EV driving-recharge time ratio a under limited grid connection. In Proceedings of the 7th IET International Conference on Power Electronics, Machines and Drives (PEMD 2014), Manchester, UK, 8-10 April 2014; pp. 1-6.

9. Mayer, M. From prototype to serial production-Manufacturing hydrogen fuelling stations. In Proceedings of the A3PS Conference 2014, Vienna, Austria, 20-21 October 2014.

10. Parks, G.; Boyd, R.; Cornish, J.; Remick, R. Hydrogen Station Compression, Storage, and Dispensing Technical Status and Costs: Systems Integration; Technical Report; National Renewable Energy Lab. (NREL): Golden, CO, USA, 2014.

11. Dicken, C.; Mérida, W. Measured effects of filling time and initial mass on the temperature distribution within a hydrogen cylinder during refuelling. J. Power Sources 2007, 165, 324-336, doi:10.1016/j.jpowsour.2006.11.077. [CrossRef]

12. Edwards, R.; Larive', J.F.; Rickeard, D.; Weindorf, W. Well-To-Tank Report Version 4.a: Jec Well-To-Wheels Analysis; EUR-Scientific and Technical Research Reports; Publications Office of the European Union: Luxembourg, 2014.

13. Bossel, U. Does a Hydrogen Economy Make Sense? Proc. IEEE 2006, 94, 1826-1837. [CrossRef]

14. Van Mierlo, J.; Maggetto, G.; Lataire, P. Which energy source for road transport in the future? A comparison of battery, hybrid and fuel cell vehicles. Energy Convers. Manag. 2006, 47, 2748-2760, doi:10.1016/j.enconman.2006.02.004. [CrossRef]

15. Campanari, S.; Manzolini, G.; Garcia de la Iglesia, F. Energy analysis of electric vehicles using batteries or fuel cells through well-to-wheel driving cycle simulations. J. Power Sources 2009, 186, 464-477, doi:10.1016/j.jpowsour.2008.09.115. [CrossRef]

16. Thomas, C. Fuel cell and battery electric vehicles compared. Int. J. Hydrogen Energy 2009, 34, 6005-6020, doi:10.1016/j.ijhydene.2009.06.003. [CrossRef]

17. Li, M.; Zhang, X.; Li, G. A comparative assessment of battery and fuel cell electric vehicles using a well-to-wheel analysis. Energy 2016, 94, 693-704, doi:10.1016/j.energy.2015.11.023. [CrossRef]

18. Felgenhauer, M.F.; Pellow, M.A.; Benson, S.M.; Hamacher, T. Evaluating co-benefits of battery and fuel cell vehicles in a community in California. Energy 2016, 114, 360-368, doi:10.1016/j.energy.2016.08.014. [CrossRef]

19. Van Mierlo, J.; Messagie, M.; Rangaraju, S. Comparative environmental assessment of alternative fueled vehicles using a life cycle assessment. Transp. Res. Procedia 2017, 25,3435-3445, doi:10.1016/j.trpro.2017.05.244. [CrossRef]

20. SAE International. J1772: SAE Electric Vehicle and Plug in Hybrid Electric Vehicle Conductive Charge Coupler; SAE International: Warrendale, PA, USA, 2016.

21. Burkhardt, J.; Patyk, A.; Tanguy, P.; Retzke, C. Hydrogen mobility from wind energy-A life cycle assessment focusing on the fuel supply. Appl. Energy 2016, 181, 54-64, doi:10.1016/j.apenergy.2016.07.104. [CrossRef]

22. Brown, T.; Stephens-Romero, S.; Scott Samuelsen, G. Quantitative analysis of a successful public hydrogen station. Int. J. Hydrogen Energy 2012, 37, 12731-12740, doi:10.1016/j.ijhydene.2012.06.008. [CrossRef]

23. Tesla 2017. Tesla Powerwall. Brochure from Tesla. Available online: https://www.tesla.com/powerwall (accessed on 23 May 2018).

24. LG Chem 2017. LG Chem ESS Products. Brochure from LG Chem. Available online: http:/ /www.lgchem. com/global/ess/ess/product-detail-PDEC0001 (accessed on 23 May 2018).

25. Höimoja, H.; Vasiladiotis, M.; Rufer, A. Power interfaces and storage selection for an ultrafast EV charging station. In Proceedings of the 6th IET International Conference on Power Electronics, Machines and Drives (PEMD 2012), Bristol, UK, 27-29 March 2012; pp. 1-6.

26. Sbordone, D.; Bertini, I.; Di Pietra, B.; Falvo, M.C.; Genovese, A.; Martirano, L. EV fast charging stations and energy storage technologies: A real implementation in the smart micro grid paradigm. Electr. Power Syst. Res. 2015, 120, 96-108. doi:10.1016/j.epsr.2014.07.033. [CrossRef] 
27. Idaho National Laboratory. Vehicle Testing-Light Duty-Electric/Advanced Vehicle Testing Activity. Available online: https:/ / avt.inl.gov / fuel-type/electric (accessed on 23 May 2018).

28. Stolten, D.; Emonts, B. (Eds.) Hydrogen and fUel Cells: Fundamentals, Technologies and Applications; Proceedings of the 18th World Hydrogen Energy Conference, Essen, Germany, 16-21 May 2010; OCLC: 844948804; Wiley-VCH: Weinheim, Germany, 2011.

29. Smolinka, T.; Günther, M.; Garche, J. NOW-Studie: Stand und Entwicklungspotenzial der Wasserelektrolyse zur Herstellung von Wasserstoff aus Regenerativen Energien; Technical Report; Fraunhofer ISE: Freiburg, Germany, 2011.

30. Stolten, D.; Samsun, R.C.; Garland, N. (Eds.) Fuel Cells: Data, Facts and Figures; OCLC: 920693385; Wiley-VCH Verlag GmbH \& Co. KGaA: Weinheim, Germany, 2016.

31. Sprik, S.; Kurtz, J.; Ainscough, C.; Jeffers, M.; Saur, G.; Peters, M. Hydrogen Station Data Collection and Analysis; National Renewable Energy Laboratory: Golden, CO, USA, 2016.

32. Clean Energy Partnership. Veröffentlichung der Projektergebnisse-Stand 01/2015. Available online: https: / / cleanenergypartnership.de/fileadmin/Assets/user_upload/Veroeffentlichung_Projektergebnisse-11_ 4_NKBF98.pdf (accessed on 23 May 2018).

33. Elgowainy, A.; Reddi, K. Hydrogen Fueling Station Pre-Cooling Analysis; DOE Hydrogen and Fuel Cells Program Annual Merit Review; Argonne National Laboratory: Lemont, IL, USA, 2015.

34. WEH GmbH Gas Technology. TK17 H2 70 MPa Datasheet. Brochure from WEH. Available online: https:/ / www.weh.com/media/itoris/attachments/t/k/tk17-h2-70mpa-enr-datasheet-e.pdf (accessed on 23 May 2018).

35. Jayakumar, A.; Chalmers, A.; Lie, T.T. Review of prospects for adoption of fuel cell electric vehicles in New Zealand. IET Electr. Syst. Transp. 2017, 7, 259-266, doi:10.1049/iet-est.2016.0078. [CrossRef]

36. Reddi, K.; Elgowainy, A.; Rustagi, N.; Gupta, E. Two-tier pressure consolidation operation method for hydrogen refueling station cost reduction. Int. J. Hydrogen Energy 2018, 43, 2919-2929, doi:10.1016/j.ijhydene.2017.12.125. [CrossRef]

37. Reddi, K.; Elgowainy, A.; Rustagi, N.; Gupta, E. Impact of hydrogen refueling configurations and market parameters on the refueling cost of hydrogen. Int. J. Hydrogen Energy 2017, 42, 21855-21865, doi:10.1016/j.ijhydene.2017.05.122. [CrossRef]

38. Karlsson, S. The variation of BEV energy use and range depending on climate and driving conditions in Sweden. In Proceedings of the EEVC Infrastructure Convention, European Electric Vehicle Congress, Geneva, Switzerland, 14-16 March 2017.

39. Robinius, M.; Linssen, J.; Grube, T.; Reuß, M.; Stenzel, P.; Syranidis, K.; Kuckertz, P.; Stolten, D. Comparative Analysis of Infrastructures: Hydrogen Fueling and Electric Charging of Vehicles. In Elektrochemische Verfahrenstechnik; Technical Report; Wiley Online Library: Hoboken, NJ, USA, 2018.

40. Gnann, T.; Funke, S.; Jakobsson, N.; Plötz, P.; Sprei, F.; Bennehag, A. Fast charging infrastructure for electric vehicles: Today's situation and future needs. Transp. Res. Part D Transp. Environ. 2018, 62, 314-329, doi:10.1016/j.trd.2018.03.004. [CrossRef]

(c) 2018 by the authors. Licensee MDPI, Basel, Switzerland. This article is an open access article distributed under the terms and conditions of the Creative Commons Attribution (CC BY) license (http:/ / creativecommons.org/licenses/by/4.0/). 